\title{
Influence of the Eagle Owl (Bubo bubo) on the Peregrine Falcon (Falco peregrinus) population in Germany
}

\section{Martin LINDNER}

Received: December 20, 2018 - Revised: January 17, 2018 - Accepted: January 20, 2019

This is a contribution submitted to the Proceedings of the World Conference on the Peregrine Falcon in Budapest in September 2017.

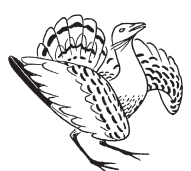

Lindner M. 2018. Influence of the Eagle Owl (Bubo bubo) on the Peregrine Falcon (Falco peregrinus) population in Germany. - Ornis Hungarica 26(2): 243-253. DOI: 10.1515/ orhu-2018-0032 the distribution and breeding success of the Peregrine Falcon. Both species compete for the same breeding sites on rocks. In addition, the Peregrine Falcon belongs to the prey spectrum of the Eagle Owl. The Eagle Owl always dominates at places where the two species meet. Since the 1980s, the Eagle Owl has taken over many of the rock face breeding sites of the Peregrine Falcon in Germany. This trend towards the taking-over of Peregrine Falcon nesting sites is ongoing in areas with rocks, as not all regions of Germany have yet been completely colonized by Eagle Owls. Since 1975, the Eagle Owl initially nested on buildings in rural areas, but it is now also colonizing urban areas. Eagle Owls are more and more frequently taking over Peregrine Falcon nest boxes on buildings. The currently growing Peregrine Falcon breeding population on buildings is expected to decline in coming years due to predation by the Eagle Owl, even though these owls do not breed very successfully on buildings and many old and young owls are killed. These statements apply to large parts of Germany. In other areas of Europe, the future usage of buildings as Eagle Owl breeding sites can be expected to have an impact on the Peregrine Falcon populations there. At least eight other Peregrine Falcon breeding sites on buildings and rocks have been taken over by Egyptian Geese (Alopochen aegyptiaca).

Keywords: breeding on buildings, Eagle Owl, Egyptian Goose, Peregrine Falcon, predation

Összefoglalás Németországban az uhu az egyetlen faj, amely jelentős hatással van a vándorsólyom elterjedésére és költési sikerére. A két faj ugyanazon sziklai fészkelőhelyekért van versenyben. Emellett, a vándorsólyom szerepel az uhu zsákmánylistáján. Az uhu minden esetben dominál, amikor a két faj együtt fordul elő. Az 1980as évek óta az uhu számos sziklai élőhelyről szorította ki a vándorsólymot Németországban. Ez a folyamat jelenleg is zajlik, mivel nem minden németországi régiót kolonizálta még az uhu. 1975-től kezdődően az uhu elkezdett fészkelni vidéki épületeken és napjainkban már a városokat is elkezdte meghódítani. Az uhuk egyre gyakrabban foglalják el a vándorsólymok számára, épületekre kihelyezett fészkelöládákat. A jelenleg növekvő, városokban, épületen fészkelő vándorsólyom-állomány várhatóan csökkeni fog az uhu-predáció hatására, annak ellenére, hogy ezek a baglyok nem túl sikeresen költenek épületen, sok öreg és fiatal madár elpusztul. A folyamat Németország nagy részére igaz. Európa más részein is várható, hogy az uhu épületeken fog fészkelni, ami hatással lesz az érintett vándorsólyom állományokra. Legalább nyolc vándorsólyom fészkelőhelyet épületen és sziklán nílusi lúd (Alopochen aegyptiaca) foglalt el.

Kulcsszavak: fészkelés épületen, uhu, nílusi lúd, vándorsólyom, predáció 


\section{Introduction}

Everywhere in Europe where there is a rather dense Eagle Owl population, the species has an influence on the population of Peregrine Falcons. It has long been known that the Peregrine Falcon can fall prey to the Eagle Owl (Uttendörfer 1939). Peregrine Falcons and Eagle Owls can compete for the same rock face, and indeed for the same breeding niche. The Eagle Owl is capable of taking both adult and juvenile Peregrine Falcons. Although the predation by the Eagle Owl and the competition for breeding sites were briefly mentioned in various publications on the Peregrine Falcon, statements regarding the scope and importance of these aspects have been lacking (Hickey 1969, Glutz von Blotzheim et al. 1971, Fischer 1977). For example, in 1993 Ratcliffe only wrote "there are a good many records of falcons being killed by them." The exact influence of the Eagle Owl on the Peregrine Falcon population was not noticed for a long time because the Eagle Owl had become extinct due to persecution in many parts of Europe, or else its surviving populations were very small. In 1965, only about 100 Eagle Owl breeding pairs existed in Germany. By contrast, in 1950 there were about 1000 pairs of Peregrine Falcons in the country (Rockenbauch 1998). The few Eagle Owls simply did not come into contact with the Peregrine Falcon population. Since the 1970s, the populations of Eagle Owl and Peregrine Falcon have again increased strongly in Germany thanks to protective measures and reintroductions, and according to Wegner (in correspondence) the population numbered 1,300 to 1,400 pairs in 2016. Information sources differ regarding the Eagle Owl population size in Germany. Territory mapping carried out from 2005 to 2014 for a distribution atlas indicated 2,100 to 2,500 territories (Gedeon et al. 2014). However, this was almost certainly an underestimate, as the mapping was not specifically aimed at owls such as Eagle Owls. Another estimate is that 4,000 to 5,000 breeding territories are occupied in Germany (Mikkola 2013). Today, Eagle Owls have displaced Peregrine Falcons from many former rock-face territories. The relationship between the two species has meanwhile become even more explosive, as the Eagle Owl is increasingly colonizing buildings and urban areas where the majority of Germany's Peregrine Falcons today breed. In the German federal state of Baden-Wuerttemberg, it was already well documented in 1985 that the Eagle Owl is the only species in Europe which has a massive influence on the distribution and breeding success of the Peregrine Falcon. In 1984, about 10\% of the potential falcon fledglings were lost due to the presence of Eagle Owls in the breeding territories (Schilling \& Rockenbauch 1985).

\section{Behaviour of the Peregrine Falcon in the presence of Eagle Owls}

If Eagle Owls are present in the vicinity of a Peregrine Falcon breeding site, the falcons show a general nervous behaviour. If an Eagle Owl is visible near the Peregrine Falcon nest, the falcons utter persistent alarm calls. If this occurs at the beginning of the breeding season, they constantly fly around the breeding site calling all the time. The direct vicinity of the former breeding site is avoided. Often, there is a change of partner or a partner disappears. Also, the breeding attempt often commences later than normal. It is striking that if an Eagle Owl is present, the female falcon often only lays two eggs. Clutches of two eggs are rare in 
Peregrine Falcons and usually only occur if the breeding site is disturbed in some way. The Eagle Owl is evidently a cause of considerable stress for the Peregrine Falcons and causes smaller clutch sizes. If the falcons achieve any breeding success at all, only one or two young birds usually fledge. Young falcons often disappear before or after fledging (Schilling \& Rockenbauch 1985, Hepp et al. 1995, Lindner \& Fruhen 1999). In East Germany, young falcons were killed in about 100 cases before and only in five cases after fledging. Adult falcons are apparently only killed directly at the breeding niche (Kleinstäuber pers. com.). Presumably, however, the number is likely to be larger, since controls by ornithologists are usually less intensive after the young birds fledge. Peregrine breeding success remains well below the average of the overall population if Eagle Owls are present. Due to the inconspicuous behaviour of the Eagle Owls, observers often do not register that they are responsible unless they directly take over the Peregrine Falcon breeding site. Therefore the losses of Peregrine Falcons due to Eagle Owls are mostly underestimated. Even observers involved in intensive nest monitoring often report that the site was abandoned for unknown reasons or because of disturbance, or that the clutch simply failed to hatch. Only with high observation intensity and intensive control of the fledged young falcons can the extent of Eagle Owl influence be accurately determined. Loss of the female falcon can often only be detected by a difference in the rings, as a substitute female may already move in on the second day after the original female Peregrine has disappeared (Kleinstäuber pers. com.). Young falcons very often disappear without a trace. Occasionally, the plucked feathers of missing falcons are discovered, or their remnants are found in Eagle Owl pellets at the nearest owl nest site. At a rock face site in Thuringia, Eagle Owls have killed Peregrine Falcons 25 times in 28 years. The victim was often the female falcon brooding eggs or sheltering the young. Finally, the breeding niche was closed off to prevent further use. The falcons moved to another site and subsequently had breeding success in $50 \%$ of the following years because they no longer nest directly in the vicinity of the Eagle Owl site (Kleinstäuber pers. com.).

If the Eagle Owl breeds at a Peregrine Falcon site, either on a rock face or on a building, sometimes even in the same niche or nesting box, Peregrine Falcon pairs respond in different ways. The majority of pairs simply do not breed. However, they generally remain at the breeding site or in its vicinity. They may still breed even very late in the year if the Eagle Owls have left in the meantime. Otherwise, they will breed only in years when the Eagle Owls do not breed.

The smallest distance between a breeding pair of Peregrine Falcons and a pair of Eagle Owls in Germany was $6 \mathrm{~m}$ in 2006 at the castle ruins of Niederhaus in Bavaria. As was to be expected, the falcons were unsuccessful (Mebs 2010). Under such circumstances the falcons are nervous and sometimes fly mock attacks. During such mock attacks the wildly calling falcon flies as close as $3 \mathrm{~m}$ to the female Eagle Owl. The owl generally shows no reaction other than looking at the flying falcon. In one case, mock attacks were flown for 40 minutes. In the end, the female Eagle Owl simply closed its eyes. The non-brooding bird of the Peregrine Falcon pair often sits in a place from which it can observe the Eagle Owl nest (Lindner \& Fruhen 1999). In most such cases, breeding is almost always unsuccessful. This is generally true for Peregrine Falcon nests located at a distance of $400 \mathrm{~m}$ or less from Eagle Owl sites. Many breeding sites are abandoned by the Peregrine Falcon after only a few years. 


\section{Influence on peregrine breeding in Baden-Württemberg}

In Baden-Württemberg (BW) with its area of $35,751 \mathrm{~km}^{2}$, there were 239 Peregrine territories and 224 occupied Eagle Owl territories in 2017 (Rau et al. 2017). The Peregrine Falcon never died out in BW and had its lowest point in 1972 with 26 territorial pairs. The population subsequently increased to 294 pairs in 2003, after which a decline set in. The Eagle Owl, however, had its last breeding success for many years in 1937. Only since 1963 has the Eagle Owl again colonized BW, and since then its population has been steadily increasing. However, the number of broods slumps in some years, probably due to adverse weather (Rau 2015).

For BW the most extensive published data in Germany are available for the influence of the Eagle Owl on breeding Peregrines. For the period 1969 to 1997 documentation proved $147 \mathrm{x}$ breeding prevented, $103 \mathrm{x}$ clutch abandoned, $59 \mathrm{x}$ young bird disappeared or killed, $11 \mathrm{x}$ number of young reduced due to massive disturbance, $30 \mathrm{x}$ adult birds or at least independent falcons (after August) killed (Rockenbauch 1998). The data quoted above relate exclusively to Peregrines breeding on rock faces, because from 1970 to 1988 , the species only bred on natural rocks and quarries in BW. From 1987 to 2015, the proportion of rock face nests fell from $100 \%$ to $62 \%$. From 1988 to 2015 , the proportion of nests on buildings or man-made structures increased from $0 \%$ to $31.8 \%$. In addition, $6.2 \%$ of nests were located on high voltage pylons. In 2015, Peregrine nests on structures and high-voltage masts made up $38 \%$ of the overall number of nests and $46 \%$ of the successful pairs, thus contributing significantly to breeding success in BW. Nests located on anthropogenic breeding sites are therefore overproportionally successful. In BW, this is mainly due to competition with the Eagle Owl. From 1965 to 2015, 4.5\% of Eagle Owl nests were on man-made structures. In recent years, this proportion has continued to rise, as has the proportion of clutches laid on the ground and on nests built by other bird species on trees, since most suitable rock-face sites are already occupied (Rau 2015).

\section{Influence on peregrine breeding in North Rhine-Westphalia}

In North Rhine-Westphalia (NRW) with its area of $34,110 \mathrm{~km}^{2}$, there were 228 Peregrine pairs in 2016 (Arbeitgemeinschaft Wanderfalkenschutz Nordrhein-Westfalen 2016) and 525 to 570 occupied Eagle Owl territories (Jöbges 2016). The Peregrine Falcon did not breed in NRW from 1971 to 1986 and the Eagle Owl was absent from the early 1960s until 1975 (Lindner 2014). Only three of the 228 Peregrine Falcon pairs in NRW still breed on rocks or in quarries. In fact, over the past few decades there have never been more than three to five breeding pairs of Peregrine Falcon in such sites per year. There is only one recorded case of a Peregrine pair moving into a quarry that was already occupied by breeding Eagle Owls. All other cases involved Eagle Owls moving into Peregrine territories. Virtually all the larger rocks and quarries have been populated by the Eagle Owl. Even at the few rock sites with Peregrine Falcon nests, there are cases of predation by Eagle Owls breeding at the same site or in the vicinity. Thus, practically the entire NRW population of the Peregrine 
Falcon breeds on buildings. Peregrine populations that almost exclusively nest on buildings are otherwise only found in a few other lowland areas of Europe and parts of the USA (Cade \& Burnham 2003).

In only a few cases where both species occupied neighbouring territories was the Peregrine Falcon successful, and this only if the Eagle Owl did not breed that year. In 1999, however, there was the exceptional occurrence where two Peregrine Falcon pairs succeeded in very close proximity to active Eagle Owl nests. One of these was at the Bornstein, part of the Bruchhauser Steine rock formation, where the Eagle Owl bred for the first time in more than 100 years. Both species successfully fledged one young. The Peregrines bred on the north side of the rock and the Eagle Owls on the south side, with a distance of 50 to 60 $\mathrm{m}$ between the nests. At the second site in a quarry at Burg, one Peregrine Falcon fledged, while the three young Eagle Owls in a nest $40 \mathrm{~m}$ distant disappeared without trace (Lindner \& Fruhen 1999). These two broods in 1999 have remained extreme exceptions for Germany. The breeding site at the Bruchhauser Steinen can be considered as typical for a site where Peregrine Falcons bred without and with the presence of Eagle Owls. In a 5-year period between 1989 and 1994, without presence of Eagle Owls, 17 young falcons fledged and the number of young averaged 2.83. In the 22 years of 1995 to 2017, with presence of Eagle Owls, 20 young falcons fledged and the number of young averaged 1.10. In some years young Peregrines were predated after fledging, as in 2000 ( 3 young).

Up to the year 2000, Eagle Owls bred in NRW almost exclusively in quarries and rock faces. Since 2000, the species has been increasingly breeding on buildings, on the ground and on other large birds' nests, as all the suitable rock face sites are occupied. From 2011 onwards, Eagle Owls appeared at Peregrine breeding sites on buildings in NRW.

At Oettinger Brewery in Mönchengladbach, the Peregrine has been breeding since 2011. Eagle Owls appeared in 2016. A second nesting box, only $10 \mathrm{~m}$ from the old Peregrine box, was installed in an attempt to allow both species to breed. The persons taking care of the site thought that the two species would breed peacefully next to each other if they both had nest boxes. Both species in fact bred, but the male Eagle Owl killed the young falcons. The predation was recorded by cameras that had been installed in both nest boxes. At the end of 2016 the Eagle Owl nesting box was removed. In 2017, only a single Eagle Owl was seen.

At the Asdonkshof Waste incineration plant an Eagle Owl pair took over a Peregrine nesting basket at a height of $100 \mathrm{~m}$ on the chimney and laid an egg. After a disturbance, the Eagle Owl pair abandoned the nest. Around the $22^{\text {nd }}$ of April the Peregrine Falcons laid three eggs. The three young Peregrines fledged successfully (Kladny 2017). This site is likely to be the highest Eagle Owl nest on a building anywhere in the world.

In 2017, a pair of Peregrines Falcons bred in a small niche without a landing board on the south side of the south tower of Xanten Cathedral while Eagle Owls bred in the Peregrine nesting box on the east side of the north tower about 15 to 20 metres distant. The only young falcon to hatch, a female, landed on the ground before it could fly properly. To prevent it being killed by the Eagle Owls, this bird was added to a clutch of young falcons at another breeding site (Kladny pers. com.).

At the tower of St. Mary's Basilica (aka St. Mary's Church) in Kevelaer, lay 2017 an eagle owl clutch in the nesting box and two metres away a peregrine clutch in the gutter. Probably 
the female eagle owl first laid a clutch there and later gave up. After abandoning the eagle owl clutch, the peregrine falcon females laid its clutch. Further details are not known (Kladny pers. com.).

In the administrative districts of Arnsberg and Münster (sub-regions of NRW), 15\% of the Peregrine Falcon territories on buildings and structures had been taken over by Eagle Owls by 2014 (Lindner 2014).

\section{Eagle Owls nesting on buildings in Germany}

Eagle Owls use of buildings as nest sites had been widely known in the former German empire since the $16^{\text {th }}$ century (Gessner 1555). Gessner wrote in 1555 that the Eagle Owl readily bred in ruins and churches. Breeding on buildings was by no means peculiar to Germany in former times, but occurred in many countries. In 1622, for example, Giovanni Pietro Olina wrote that in Italy the Eagle Owl inhabited dilapidated ruins, holes in walls and the roofs of deserted houses (Olina, \& Macdonald 2018). Until the end of the $19^{\text {th }}$ century, almost all German literature about the Eagle Owl mentioned breeding on buildings. The last three proven breeding occurrences on buildings took place in the 1880s. After that, there was a gap in documented cases until one in 1929 and then a further gap until 1975 (Lindner 2014).

By contrast, Peregrine Falcon nests on buildings in Germany have surprisingly been found only from 1809 onwards. Since nesting on buildings was never mentioned in previous literature, they must, if they existed at all, have been very rare. Until 1970, Peregrine Falcons' nests on buildings used to be found mostly in ruins and churches, just as in the case of the Eagle Owl in earlier times (Kuhk 1969, Mebs1969). Since Peregrines again started nesting on buildings in 1978, they have usually been found on modern structures such as power stations, bridges, industrial plants and pylons. However, some older buildings, such as churches, castles, etc., including historical breeding sites, are also occupied or re-occupied by the species. The Peregrine Falcon shows a far greater tolerance of disturbance than the Eagle Owl.

In various parts of Germany, Eagle Owls took over Peregrine nest sites on buildings from 1990 onwards. This trend accelerated from 2010 onwards. Increasingly, the Eagle Owl is also breeding in Peregrine nesting boxes (Lindner 2016). From 1975 to 2016 at least 170 buildings in Germany were known to be Eagle Owl breeding sites. These comprised 45 castles, castle ruins or similar, 50 industrial buildings and commercial buildings, 20 buildings in quarries and sand and gravel pits, 27 churches, 8 road and railway bridges, 4 telecommunications towers, 4 detached houses, 2 multi-storey buildings and 10 other structures. Extreme cases were nests on a funerary monument, an ammunition bunker, a submarine bunker and a bullet trap of a firing range. Prior to 1975 , only ruins, castles, fortifications and churches had been known as breeding places (Lindner 2016). In 2016, at least 60 buildings were occupied by Eagle Owls Pairs, but breeding could not always be proved. At least 30 other buildings were occupied by single Eagle Owls, although in some of these cases it is possible that a pair was present but the second owl was overlooked. All these figures from recent decades are minimum numbers, as there are data gaps. 
On the Neverstaven telecommunications tower in Schleswig-Holstein, situated on the 78 $\mathrm{m}$ high hill called Klingberg in an otherwise flat landscape, an Eagle Owl pair bred in 2008 and 2009 in a Peregrine nesting box at a height of $50 \mathrm{~m}$. In 2010, a second Peregrine Falcon nesting box was installed at a height of $97 \mathrm{~m}$ (Robitzky 2010). In 2013, both species simultaneously attempted to breed for the first time, although the Peregrine Falcons were unsuccessful (Lindner 2016). Until 2017, there were other attempts at simultaneous breeding of both species, and at least in some years both Eagle Owl and Peregrine Falcons fledged. One interesting fact is that Eagle Owl droppings and pellets were also found on the platform with the Peregrine Falcon nest at $97 \mathrm{~m}$ (Robitzky pers. com.).

The period that individual buildings were occupied by Eagle Owls varied from 1 to 25 years. Only eight buildings were occupied for more than ten years. However, many nesting sites on buildings were occupied for only one or two years. On several occasions, breeding took place on buildings at heights of 50 to 70 meters. Clutches of eggs have been abandoned on a number of occasions after disturbance at the nest, and the Eagle Owls usually gave up such disturbed sites permanently. Eagle Owl fledglings move away from the nest site from the age of 45 days and explore the surrounding area (Penteriani et al. 2004). During this phase, they often jump from the building if there is no other way of leaving the direct vicinity of the nest successfully (Harbeck 1995). The higher the jump and the harder the landing place, the greater is the risk that the young owl will injure itself or crash to its death. Hard edges, fences and other sharp objects as well as shafts in the landing area increase the risk of injury to the young birds. In 2009, a fledgling survived the jump from a height of 50 $\mathrm{m}$ at the Neverstaven telecommunications tower in Schleswig-Holstein (Robitzky 2010). In 2017, one of two fledglings that jumped from a height of $65 \mathrm{~m}$ at the Luther Church in Kassel was killed (Löver 2018). There have been repeated cases of young Eagle Owls being picked up and brought to care stations after jumping to the ground in inner cities. These were then reared in the care stations and later returned to the wild (Lindner 2016). In some cases, after young birds had jumped from the nest the areas where they were located were closed off to humans, or else the birds were moved to safe areas from which they could eventually fly off (Harms 2016, Löver 2018). Presumably, the dangers due to road and rail traffic, impact against power lines, etc. are also larger in towns and cities and in the nearby feeding areas of urban Eagle Owls.

Eagle Owl nests on buildings have also been found in the last two decades in Spain, Sweden, Belarus, Austria, Italy, Finland, France and Russia. Today, in many parts of Europe more and more Eagle Owls are to be found on buildings, even in large cities. The cities where Eagle Owls have been recorded nesting on buildings include Stockholm, Helsinki, Madrid, Córdoba, Jerez de la Frontera, Trento, Budapest, Lyon and Marseille (Lindner 2016). This list of the countries and cities with Eagle Owl nests on buildings is very probably incomplete. While Peregrine Falcon nest boxes have been attached to structures in many countries of the world since the 1980s, probably the first Eagle Owl nest boxes were installed on buildings in Helsinki in 2007, (Lindner 2014). However, Eagle Owl nest boxes are probably still extreme exceptions in Europe. 


\section{Protective grating to prevent Eagle Owls from using Peregrine breeding sites}

In eastern Germany and Baden-Württemberg, protective grating has sometimes been installed to prevent Eagle Owls from accessing Peregrine Falcon breeding sites in rock faces and on structures (Rauh and Kleinstäuber pers. com.). Experience shows that the bars should have a max. spacing of $17 \mathrm{~cm}$ because larger grid spacing has failed to stop Eagle Owls from using the nesting boxes or rock niches. The smaller the spacing the better, so that the Eagle Owl really has no chance to squeeze through. A determined Eagle Owl can force itself through grating bars spaced larger than $17 \mathrm{~cm}$. Also, the distance of the grating from the nest hollow in the eyrie must be so large that the Eagle Owl with its amazingly long legs and claws cannot reach the falcons when it is pressing against the grating (Kleinstäuber pers. com.). All protective gratings installed so far have been at long-standing Peregrine Falcon nest sites. In spite of the protective grating, Eagle Owls can still take the young falcons during the begging phase, when they roost outside the protective grating. Even if protective grating is installed, the Eagle Owl can still disrupt the breeding by its pure presence. As the Eagle Owl is much more flexible in its choice of nest site, it can easily find a place in the immediate vicinity and still continuously bother the Peregrines. It is not possible to install protective grating on many rock-face breeding sites in Germany, as almost all of them have been designated as protected areas. In Peregrine Falcon protection societies in Germany, the installation of protective grating is a controversial subject.

\section{Egyptian goose as a competitor for Peregrine Falcon nesting boxes}

In recent years, Egyptian Geese have taken possession of some rock face breeding niches and nesting boxes of Peregrine Falcons in various regions of western Germany. In most cases, the Peregrine does not manage to defend its breeding site against Egyptian Geese. Egyptian Geese taking over nesting sites of Peregrine Falcons is a new phenomenon. Mostly, this concerns nesting boxes.

Since the late $18^{\text {th }}$ century, Egyptian Geese derived from captive stock have been breeding in the UK. This population was long restricted to southeast England. However, since the 1970s the species has spread via the Netherlands to Belgium, France and Germany (Venema 1997). In the meantime, it has also colonized Switzerland, Austria and Poland. Egyptian Geese first bred in Germany in 1981. A census conducted from 2000 to 2009 already registered 5,000 to 7,500 territorial pairs (Gedeon et al. 2014).

According to incomplete data, Egyptian Geese took over Peregrine Falcon nest sites or disturbed the breeding falcons on at least 8 occasions in Germany up to 2017. At the Heiliggeist church in Heidelberg, a computer-controlled image recognition system was installed in a Peregrine nesting box in order to drive away Egyptian Geese. When Egyptian Geese entered the box, they were driven away by noise and flickering lights. When the PC registered a Peregrine Falcon image, no action was initiated. The Peregrine Falcons bred successfully (Gäng $\&$ Soergel 2016). If there are different nesting possibilities at one site, Peregrine Falcon and Egyptian Goose can also nest close to each other. In 2010, both species successfully bred in 
nests five metres apart on the keep of Burg Zwingenberg castle in Baden-Württemberg (Edelmann 2010). As a result of the current increase in size of Egyptian Goose populations all over Europe and their expansion into further areas, the Peregrine is likely to be driven out of even more breeding sites. Usually, however, the Egyptian Geese take over the Peregrine Falcon nest site for a few years only.

\section{Conclusions}

The ongoing increase in Eagle Owl populations in Germany, parts of Central Europe, Western Europe and Scandinavia will presumably continue to have a negative impact on the breeding success and distribution of Peregrine Falcons on rock faces, buildings and structures. Today, the food availability for Eagle Owls is likely to be better in cities than in many agricultural areas with their endless expanses of maize. In towns and cities there are plenty of prey animals of optimal size, such as pigeons, brown rats, rabbits and the waterfowl on city waters (Görner 2013, Lindner 2016). In the future, food availability for Eagle Owls is unlikely to deteriorate in Europe's towns and cities, which will therefore continue to be a magnet as the species' population levels grow. It can therefore be assumed that there will be a strong increase in the number of Eagle Owls nesting on buildings and structures over the next few years. In the course of this, it can be expected that a wide range of structures will be chosen as breeding sites. It is likely that the Eagle Owl will breed most successfully on buildings in rural areas. At or in the vicinity of buildings such as television towers, bridges and industrial buildings in the countryside there are usually significantly fewer flight obstacles than in urban areas and young Eagle Owls probably have better chances of survival in the branchling and post-fledging phases. There will be a growing competition between Peregrine Falcons and Eagle Owls for nest sites, both on buildings in cities and on buildings outside densely populated areas.

In the coming decades, the increase in Eagle Owls nesting on buildings will presumably lead to a decline in the number of breeding Peregrines in Germany. However, it is important to note that up to now Eagle Owl pairs have often nested on buildings in urban areas for periods of only 1 to 3 years, and only achieve a low fledging success rate. Often, adult and juvenile owls are found dead or injured because they have flown into obstacles or collided with road traffic. It is hardly possible to predict how great the negative impact of the Eagle Owl on the Peregrine population on buildings will actually be. The influence of the Eagle Owl on the Peregrine population is natural and cannot be influenced by nature conservationists. In Germany, many rock faces were populated by Peregrine Falcons as late as the $19^{\text {th }}$ century or early $20^{\text {th }}$ century only after the local Eagle Owls were eradicated by massive persecution. Presumably, in the $19^{\text {th }}$ century and earlier the number of Peregrine Falcons was significantly smaller than today in many parts of Germany (Lindner 1998).

\section{Acknowledgement}

Christopher Husband kindly translated the text from German into English. 


\section{References}

Arbeitsgemeinschaft Wanderfalkenschutz Nordrhein-Westfalen (AGW). 2016. Brutergebnisse des Wanderfalken in Nordrhein-Westfalen im Jahr 2016. [Breeding success of Peregrine Falcons in North Rhine - Westphalia in 2016] - Jahresbericht Arbeitsgemeinschaft Wanderfalkenschutz des NABU NRW 23: 4-9. (in German)

Cade, T. J. \& Burnham, W. 2003. (ed.). Return of the Peregrine: A North American saga of tenacity and teamwork. - The Peregrine Fund, Boise

Edelmann, J. 2010. Nilgansbrut in unmittelbarer Nachbarschaft zur Wanderfalkenbrut [Egyptian Goose breeding in immediate neighbourhood of a Peregrine breeding]. - Arbeitsgemeinschaft Baden-Württemberg Jahresbericht 2010: 6. (in German)

Fischer, W. 1977. Der Wanderfalk. Die Neue Brehm Bücherei [The Peregrine Falcon]. - A. Ziemsen Verlag, Wittenberg (in German)

Gedeon, K., Dougalis, P., Grüneberg, C., Mitschke, A., Sudfeldt, C., Eickhorst, W., Fischer, S., Flade, M., Frick, S., Geiersberger, I., Koop, B., Kramer, M., Krüger, T., Roth, N., Ryslavy, T., Stübing, S., Sudmann, S., Steffens, R., Vökler, F. \& Witt, K. 2014. Atlas deutscher Brutvogelarten [Atlas of German breeding birds]. Münster, Stiftung Vogelmonitoring Deutschland \& DDA (in German with English Summary)

Glutz von Blotzheim, U., Bezzel, E. \& Bauer, K. M. 1971. Handbuch der Vögel Mitteleuropa. Bd. 4 Falconiformes [Guide to the birds of Central Europe]. - Akademische Verlagsgesellschaft, Frankfurt am Main (in German)

Görner, M. 2013. Der Uhu (Bubo bubo) im urbanen Siedlungsraum [The Eagle Owl in urban settlement areas]. Beiträge zur Jagd- und Wildforschung 38: 437-445. (in German with English Summary)

Gäng, H. M. \& Soergel, E. 2016. Erfolgreiche Vergrämung der Nilgänse aus dem Wanderfalkenkasten der Heiliggeistkirche in Heidelberg [Successful deterrence of Egyptian Geese from the Peregrine Falcon nest box on the Heiliggeistkirche in Heidelberg]. - Arbeitsgemeinschaft Baden-Württemberg Jahresbericht 2017: 4-8. (in German)

Harbeck, S. 1995. Brutvorkommen des Uhus (Bubo bubo) in Lüneburg [Presence of breeding Eagle Owls (Bubo bubo) in Lüneburg] - Jahresberichtung. - Naturwissentschaftliche Verlag. Fürstentum Lüneburg 40: 133150. (in German)

Harms, C. 2016. Bauwerkbruten des Uhus (Bubo bubo) - Fallbeispiele zu Konflikten und Problemlösungen [Eagle Owls (Bubo bubo) breeding on buildings - Examples for conflicts and problem solutions]. - Naturschutz südlicher Oberrhein 8: 23-246. (in German)

Hepp, K., Schilling, F. \& Wegner, P. 1995. Schutz dem Wanderfalken - 30 Jahre Arbeitsgemeinschaft Wanderfalkenschutz (AGW) [Conservation oft he Peregrine Falcons - 30 years of Peregrine Falcon Conservation Working Group (AGW)]. - Beihefte zu den Veröffentlichungen. Naturschutz Landschaftspflege. Baden-Württemberg. 46, Karlsruhe (in German)

Hickey, J. J. 1969. Peregrine Falcon Populations. - University of Wisconsin Press, Madison

Jöbges, M. 2016. Zum Vorkommen des Uhus (Bubo bubo) 2015/16 in Nordrhein-Westfalen - Trend, Beeinträchtigung, Interaktion [To the occurence of Eagle Owls (Bubo bubo) 2015/16 in North Rhine - Westphalia Trend, disturbance, interaction]. - Jahresbericht Arbeitsgemeinschaft Wanderfalkenschutz des NABU NRW 23: 10-17. (in German)

Kladny, M. 2017. Einflussnahme des Uhus auf das Brutverhalten des Wanderfalken [Influence of Eagle Owls on the breeding behaviour of Peregrine Falcons]. - Jahresbericht Arbeitsgemeinschaft Wanderfalkenschutz des NABU NRW 23: 23. (in German)

Kuhk, R. 1969. Weiteres über Bruten des Wanderfalken (Falco peregrinus) an menschlichen Bauwerken [Further data on Peregrine Falcon (Falco peregrinus) breeding on buildings]- DFO-Jahrbuch 1968: 65-66. (in German)

Lindner, M. 1998. Der Uhu als bestandslimitierender Faktor für den Wanderfalken im Sauerland [The Eagle Owl as population limiting factor for the Peregrine Falcon in Sauerland] - Jahresbericht Arbeitsgemeinschaft Wanderfalkenschutz des NABU NRW 11-13. (in German)

Lindner, M. 2014. Uhubruten an Bauwerken und in urbanen Räumen [Eagle Owl breedings on buildings in urban areas]. - Der Falke 61: 21-25 (in German)

Lindner, M. 2016. Uhu als Bauwerksbrüter in Deutschland [Eagle Owl as „building-breeder“ in Germany]. - Eulenrundblick 66: 90-95. (in German with English Summary)

Lindner, M. \& Fruhen, M. 1999. Erfolgreiche Falkenbruten im Hochsauerlandkreis in enger Nachbarschaft zum Uhu [Successful breeding of falcons in Hochsauerlandkreis in close neighbourhood of Eagle Owl]. - Jahresbericht Arbeitsgemeinschaft Wanderfalkenschutz des NABU NRW 13-15. (in German) 
Löver, S. 2018. Erstmals brütet ein Uhu im Lutherturm in Kassel (Hessen) [First breeding of Eagle Owl on Lutherturm in Kassel (Hessen)]. - Eulenrundblick 68: 91-92. (in German with English Summary)

Mebs, T. 1969. Wanderfalken brüten an menschlichen Bauwerken [Peregrine Falcons breeding on buildings]. DFO-Jahrbuch 1968: 55-65. (in German)

Mebs, T. 2010. Bemerkenswerte Bruten von Uhus Bubo bubo an Ruinen oder anderen menschlichen Bauwerken [Remarkable breedings of Eagle Owls Bubo bubo on ruins or other buildings]. - Eulenrundblick 60: 75-76. (in German with English Summary)

Penteriani, V., Delgado, M. M., Maggio, C. Aradis A. \& Sergio, F. 2004. Development of chicks and predispersal behavior of young in the Eagle Owl Bubo bubo. - Ibis 147: 155-168. DOI: 10.1111/j.1474-919x.2004.00381.x

Gessner, C. 1555. Historia animalium - Lib III. De avium natura [Animal history]. - Forschauer, Zürich (in Latin)

Mikkola, H. 2013. Handbuch Eulen der Welt [Guide to the Owls of the world]. - Kosmos, Stuttgart (in German)

Olina, G. P. \& Macdonald, H. 2018. Pasta für Nachtigallen: Ein Handbuch über Vogelpflege aus dem 17. Jahrhundert [Pasta for Nightingales: A Handbook on 17th Century Bird Care]. - Gerstenberg Verlag, Hildesheim (in German)

Ratcliffe, D. A. 1993. The Peregrine Falcon. - Poyser, London

Rau, F. 2015. Bestands- und Arealentwicklung von Wanderfalke Falco peregrinus und Uhu Bubo bubo in Baden-Württemberg [Population dynamics and spatial development of Peregrine Falcon Falco peregrinus and Eagle Owl Bubo bubo in Baden-Württemberg]. - Ornithologische Jahreshefte für Baden-Württemberg 31: 99127. (in German with English Summary)

Rau, F., Becht, J., Lühl, R. \& Fischer, B. 2017. Wanderfalken und Uhu in Baden-Württemberg - Die Brutsaison 2017. [Peregrine Falcons and Eagle Owls in Baden-Württemberg]. - Arbeitsgemeinschaft Baden-Württemberg Jahresbericht 2017: 4-8. (in German)

Robitzky, U. 2010. Erfolgreiche Uhubrut in einer Wanderfalkennisthilfe auf einem Fernsehturm [Successful Eagle Owl breeding in an artificial Peregrine Falcon nest on a television tower]. - Vogelkundliche Berichte zwischen Küste und Binnenland Bd. 9. H. 1: 39-41 (in German)

Rockenbauch, D. 1998. Der Wanderfalke in Deutschland und umliegenden Gebieten, Band 1. [The Peregrine Falcon in Germany and neighbouring areas, Volume 1.]. - Verlag C. Hölzinger, Ludwigsburg (in German)

Schilling, F. \& Rockenbauch, D. 1985. Der Wanderfalke in Baden-Württemberg [The Peregrine Falcon in Baden-Württemberg]. - Beihefte zu den Veröffentlichungen. Naturschutz Landschaftspflege. Baden-Württemberg. 46, Karlsruhe (in German)

Uttendörfer, O. 1939. Die Ernährung der deutschen Raubvögel und Eulen und ihre Bedeutung in der heimischen Natur [The diet of German birds of prey and owls and their importance in the native nature]. - Neudamm-Neudamm, Berlin (in German)

Venema, P. 1997. Alopochen aegyptiaca - Egyptian Goose. - In: Hagemeijer, W. J. M. \& Blair, M. J. (eds.) The EBCC Atlas of European Breeding Birds - Their distribution and abundance. - Poyser, London, p. 79.

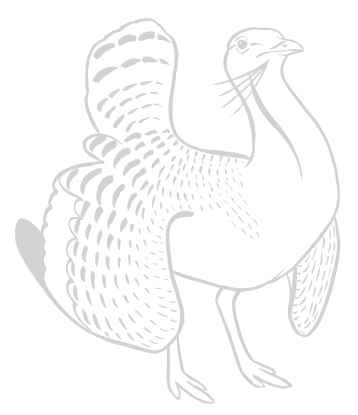

